\title{
The Effects of Foliar Boron and Silica Through the Leaves on Soybean Growth and Yield
}

\author{
Paul Benyamin Timotiwu (Corresponding author)
}

Departement of Agronomy and Horticulture, University of Lampung,

Bandar Lampung 35145, Lampung, Indonesia.

Tel: +62-85780180922 E-mail: paul.timotiwu@fp.unila.ac.id

\section{Agustiansyah}

Departement of Agronomy and Horticulture, University of Lampung,

Bandar Lampung 35145, Lampung, Indonesia.

Tel: +62-8127274426 E-mail: agustiansyahn@yahoo.com

\section{Ermawati}

Departement of Agronomy and Horticulture, University of Lampung,

Bandar Lampung 35145, Lampung, Indonesia.

Tel: +62-85279960145 E-mail: ermawati103@gmail.com

\section{Suci Amalia}

Departement of Agrotechnology, University of Lampung,

Bandar Lampung 35145, Lampung, Indonesia.

E-mail: suciamaliafm@gmail.com

Received: May 22, 2018 Accepted: June 5, 2018

doi:10.5296/jas.v6i3.13169

URL: https://doi.org/10.5296/jas.v6i3.13169 


\section{Abstract}

This study was aimed to determine the effect of the increasing silica and boron concentration and their interaction on plant growth and soybean yield. This research was conducted from April-September 2017 in the integrated field of the experiment at the University Lampung. The treatments were 0 and $5 \mathrm{ppm}$ Boron (B) fertilizer and Silica (Si) concentrations in 6 levels $(0,25,50,75$, and $100 \mathrm{ppm})$. The difference between the means of B were calculated by using Orthogonal Contrast and response of Si was used Polynomial at $\alpha 0.05$. The results showed that application of $5 \mathrm{ppm}$ of B foliarly produced higher of soybean growth and production than without B treatment through variables of the dry weight and grain weight. Application of up to $125 \mathrm{ppm}$ of Si foliarly was improved of soybean growth and production through variables of plant height, number of leaf, leaf area, dry weight and number of productive branch, number of pods, filled pod, and grain weight, but it didn't affect the percentage of empty pods. The response of soybean growth and production to the increasing Si didn't depend on the foliar B which was showed in all variables.

Keywords: Boron; Soybean; Silica.

\section{Introduction}

Soybean ( Glycine $\max$ (L) Merril) is a food plant which has high source of nutrition. In Indonesia, soybean is the raw material for making drinks and foods stuff such as milk soy, "tempe", tofu, soy sauce, etc. According to FAOSTAT (2014), United States was the biggest country produced of soybean and its production was 82.054 .800 ton, followed by Brazil, Argentina, India and Paraguay. Indonesia was on the twelfth of its soybean production, that was 843.153 tons, while the needs of soy consumption in Indonesia were increased in every year since 2010 and it reaches 2.2 million tons for each year (CSA, 2015).

According to Sudaryono et al. (2007), the low of soybean production, which is faced until now is caused by the readiness of good quality of soybean seed is still low and less fertilization. A good quality seed is a seed which has a high viability and vigor. One of the ways to increase the quality of seed is, by fertilizing through the leaf and the readiness of ideal micronutrient for the growth and production of seeds. The effort to increase soybean production can be done by fixing the fertilizing technique.

Fertilizing is done to give additional nutrients which are needed by plants because the readiness of nutrients is limited. Fertilizing through leaf can give an effect faster and real than applying through the soil because the nutrient which is given through leaf can be absorbed directly as nutrients of nutrient. Nutrient gets into plants' tissue through cutin lining and cell wall, after that interacts directly with protoplasm, then translocated to cells which need it.

Based on the amount needs of nutrients which are needed by the plant, an essential nutrient is divided into two big groups, they are the macro and micro nutrient. Boron is one of 16 important nutrients for plants' growth. Boron is used for cell fission, pollination, fruit formation, translocation, sugar and core, synthesis amino acids, and to control metabolism carbohydrate. The readiness of boron in soil is $0,10-5,0 \mathrm{ppm}$ while normal needs of boron for monocotyledon plant is 6,0-18,00 ppm and dicotyledon plants are 20,0-60,00 ppm (Heckman, 
2009).

Silica ( $\mathrm{Si}$ ) is the second nutrient which is much in the earth's crust (Sommer, et al. 2006). According to Yukamgo and Yuwono (2007), the ability of dicotyledon plants and leguminous to absorb silica $\left(\mathrm{SiO}_{2}\right)$ is about $0.5 \%$. Plants which lack silica loses much water from plants (the transpiration is high) because the leaf surface is not protected by silicate so that the plants will dry easily. Silica functions to strengthen the epidermal tissue wall, tissue vessels, and to reduce lack of water (Makarim et al, 2007).

Based on the background which has been explained, so giving boron and silica through leaf are needed to increase the growth of soybean production. This research was done to answer these research questions:

1. How is the response of foliar boron concentration through the leaf to the growth and production of soybean plants?

2. How is the response of foliar silica concentration through the leaf to the growth and productions of soybean plants?

3. Is there any response of soybean plants in the different growth and production on giving silica concentration depends on the foliar boron concentration through leaf?

\section{Materials and Methods}

The research was conducted in the Integrated Area Laboratory and the Seed and Plant Breeding Laboratory, Universitas of Lampung from April-September 2017. The materials used were Wilis soybean variety, urea, TSP, $\mathrm{KCl}$, distilled water, Silica $\left(\mathrm{Na}_{2} \mathrm{SiO}_{3}\right)$, and Boron $\left(\mathrm{H}_{3} \mathrm{BO}_{3}\right)$. The laboratory instruments used were electronic scale with 0,01 grams sensitivity, measuring cups, polybag, hand sprayer, Konica Minolta SPAD 502 series chlorophyll meter, oven, and seed blower.

In order to answer the question of research questions and to find hypothesis testing, the treatment design was arranged factorially $(2 \times 6)$ and there was triple in every regulation. The first factor was boron's dose which consisted of 2 concentration levels they are 0 ppm (B0), 5 ppm (B1). The second factor was Silica's dose which consisted of 6 concentration levels, they are 0 ppm (S0), 25 ppm (S1), 50 ppm (S2), 75 ppm (S3), 100 ppm (S4) and 125 ppm (S5). The micronutrient $\mathrm{B}$ and $\mathrm{Si}$ was applied three times started on day 21 after planting with a 4-week interval. The boron application was done in the morning from 7:00-9:00 pm, and silica applied in the evening from 3:00-5:00 pm. The treatments were applied to the entire surface of the leaves of soybean plants. The B and Si was applied on the same day, and B was first applied to the soybean leaves, followed by Si.

Sand media were used for planting medium. Sand was washed 7 times to remove mineral content and dried. Sand was filled into a $10 \mathrm{~kg}$ of polybag. Boron and Silica applied 3 times during the 3,6,9 weeks after planting (WAP). Concentration of $\mathrm{B}$ in form of $\mathrm{H}_{3} \mathrm{BO}_{3}$ were 0 and $5 \mathrm{ppm}$, while the $\mathrm{Si}$ concentration in form of $\mathrm{Na}_{2} \mathrm{SiO}_{3}$ were $0,25,50,75,100$, and 125 $\mathrm{ppm}$. The initial steps to prepare a solution $\mathrm{B}$ and $\mathrm{Si}$ is to calculate the concentration of $\mathrm{B}$ and $\mathrm{Si}$ in $\mathrm{H}_{3} \mathrm{BO}_{3}$ and $\mathrm{Na}_{2} \mathrm{SiO}_{3}$ by: 
Element ppm $(\mathrm{mg} / \mathrm{l})=\frac{\text { weight of the molecule }(\mathrm{Mrr})}{\text { weight of atom }(A \mathrm{Ar})} \mathrm{x}$ concentration in ppm

SPAD value observations made when the plant enters the generative phase. Samples were taken from the greenness leaf. There were three points for measuring the greenness (base, middle, and tip of the leaf). The position of the leaf was a third leaf from the tip shoot or the youngest with fully expanded. Data was automatically saved in the memory of SPAD. The principle of this tool is to determine the chlorophyll concentration by measuring the absorbance of leaf area red and near-infrared. Light emitted by the two LEDs with a peak wavelength at $650 \mathrm{NM}$ and $940 \mathrm{NM}$ (Sub et al., 2015).

SPAD has no units of SPAD value is used as the value $(\mathrm{x})$ for the comparative correlation of core variables such as leaf area, dry weight of the plant, filled pods and grains weight. Observed variables on the plant growth and yield of soybean were plant height, number of leaf, leaf area, dry weight, number of productive branch, number of pods, filled pods, the percentage of empty pods, and grain weight. Data were then analyzed using Orthogonal Polynomial for B and Si. The entire test was done at the level $\alpha 0.05$.

\section{Result and Discussion}

The results of study showed that soybean plants were responsive to the increasing concentration levels of B and Si polynomial analysis on the level $\bar{\alpha}$ of 0.05 presented in Table 1 and 2 show that there was an interaction between the concentration of B and Si on soybean growth and yield.

Table 1. Recapitulation effect of an increase in the concentration of Si and the addition of B on the soybean growth.

\begin{tabular}{llccc}
\hline \multirow{2}{*}{ Comparison } & \multicolumn{5}{c}{ Variable } \\
\cline { 2 - 5 } & PH & NL & LA & DW \\
\hline Boron (B) & --- \%difference---- \\
P1: B0 VS B1 & ns & ns & ns & 6,78* \\
Silica (Si) & & & & \\
P2: Si-Linier & $*$ & $*$ & $*$ & $*$ \\
P3: Si-Quadratic & ns & ns & ns & $*$ \\
nteraction & & & & \\
P4: P1 x P2 & ns & ns & ns & ns \\
P5: P1 x P3 & ns & ns & ns & ns \\
\hline
\end{tabular}

Remarks: $\mathrm{B} 0=0$ ppm Boron; $\mathrm{B} 1=5$ ppm Boron; $\mathrm{PH}=$ plant height; $\mathrm{NL}=$ number of leaf; $\mathrm{LA}=$ leaf area; $\mathrm{DW}=$ dry weight. * significant at $\bar{\alpha}=5 \%$, ns $=$ not significant at $\bar{\alpha} 5 \%$. 
Table 2. Recapitulation of the effect of an increase in the concentration of $\mathrm{Si}$ and the addition of B on soybean yield.

\begin{tabular}{lccccc}
\hline \multirow{2}{*}{ Comparison } & \multicolumn{5}{c}{ Variable } \\
\cline { 2 - 6 } & NPB & NP & FP & EP & GW \\
\hline Boron (B) & & & & & \\
P1 : B0 VS B1 & ns & ns & ns & ns & $\mathbf{5 , 9 9 *}$
\end{tabular}

Silika (Si)

P2 : Si-Linier ns ns ns ns *

P3:Si-Quadratic $\quad * \quad * \quad * \quad$ ns $\quad *$

\section{Interaction}

P4 : P1 x P2 ns ns ns ns ns

P5 : P1 x P3 ns ns ns ns ns

Remarks: $\mathrm{B} 0=0$ ppm Boron; $\mathrm{B} 1=5 \mathrm{ppm}$ Boron; $\mathrm{NPB}=$ number of productive branch, $\mathrm{NP}=$ number of pods, $\mathrm{FP}=$ filled pod, $\mathrm{EP}=$ the percentage of empty pods, and $\mathrm{GW}=$ grain weight $*$ significant at $\bar{\alpha}=5 \%, \mathrm{~ns}=$ not significant at $\bar{\alpha} 5 \%$.

Table 3. Correlation analysis SPAD value with a variable vegetative and generative soybean plant.

\begin{tabular}{lccc}
\cline { 2 - 3 } \multicolumn{1}{c}{ Variable } & R-hit & R-table \\
\hline \hline Leaf Area (LA) & $\mathbf{0 , 5 9 8} *$ & $\mathbf{0 , 5 7 6}$ \\
Dry Weight (DW) & $\mathbf{0 , 8 9 1 *}$ & $\mathbf{0 , 5 7 6}$ \\
Filled Pods (FP) & $\mathbf{0 , 5 9 7 *}$ & $\mathbf{0 , 5 7 6}$ \\
Grain Weight (GW) & $\mathbf{0 , 7 6 4 *}$ & $\mathbf{0 , 5 7 6}$ \\
\hline
\end{tabular}

Remarks: $\mathrm{LA}=$ leaf area; $\mathrm{DW}=$ dry weight; $\mathrm{FP}=$ filled pods; $\mathrm{GW}=$ Grain weight. $*$ significant at $\mathrm{R}=0,576, \mathrm{~ns}=$ not significant at $\mathrm{R}=0,576$.

Foliar of Si up to $125 \mathrm{ppm}$ concentration with B $5 \mathrm{ppm}$ did not show any interaction either in growth phase (vegetative) or production (generative). This was presumably because the provision of boron and silica through the leaves have different nutrient absorption mechanisms such as crosslink / apoplast pathways and channel transporters. Boron (B) in the form of $\mathrm{B}_{3}(\mathrm{OH})_{4}$ which was absorbed into the leaves through stomata using a simple cross path. Boron itself is actually immobile in the plant, but boron can still be easily absorbed due to the presence of alcoholic sugar (polyol). Polyols bound to B are carried by water to the bundle sheath and phloem. On the phloem tissue B brings photosynthate results to be translocated to the sink to another growing point. This is in line with the opinion of Brown and Barry (1997) that boron can be mobile as long as the plant contains sugar alcohol in the form of polyol. 
Boron is absorbed through the stomata, but it cannot pass through the cell wall just because B is immobile and therefore needs a transporter. Transporter B in the plant is thought to be the genes NIP6, NIP5, and BOR1. The transporter is thought to help B through the cell membrane to mesophyll tissue, chloroplasts, vascular spaces, phloem, and sinks, and transit to other growing plant tissues. According to Tanaka et al. (2008) NIP6 is a channel transporter B for plant growth. This is in accordance with the opinion of Miwa and Toru (2010) that NIP and BOR are believed to help transport boron in plants.

Silica itself has a cross-path apoplast that cannot penetrate the endodermis directly except through the casparian strip. Silica is also the same as the immobile boron in plants that require transporter and alcoholic sugar in the form of polyol to be absorbed by the plant. According to Ma and Yamaji. (2006) Lsi1 is the gene responsible for the Si transporter to the root cell of the plant. The same is stated in the research da Silva Lobato et al. (2013) that there are at least two transporters involved in the absorption of silica in the root of the rice. One lies in the plasma membrane that helps transport the silica to the cortex or planted a mesophyll called SIT1. Both lie in the plasma membrane of the parenchymal xylem cell that helps release Si into the xylem called SIT2.

This was thought to result in the absence of $\mathrm{B}$ and $\mathrm{Si}$ interactions, due to the different absorption mechanisms of B and Si. Different B and Si absorption results in different results. According to Savic and Marjanovic (2013) that there is no interaction on the foliar of B and $\mathrm{Si}$ on the growth of sunflower. This is in line with Prihartini (2013) research that there is no interaction effect between $\mathrm{B}$ and $\mathrm{Si}$ on all growth variables, physiological activity, as well as structural strength of the epidermal tissue root of the yellow banana plant. The same result is in line withTimotiwu et al. (2016) stated in his research that there is no interaction between giving $\mathrm{B}$ and $\mathrm{Si}$ to rice plants.

The results showed that an increase of $\mathrm{Si}$ up to $125 \mathrm{ppm}$ could improve all the growth variables better than without Si (Fig. 1-4). This is in accordance with the research Sukkaew et al. (2016) that different silica foliar has a better effect on plant height variables and dried seedlings than Si. The increase in plant height as a result of Si increase is thought to affect the number of leaves. The results showed that the response of plant to Si up to $125 \mathrm{ppm}$ increased number of leaf (Fig. 3). This is in line with the research of Costa et al. (2016) that foliar of Si with concentrations of 0.28 and $0.55 \mathrm{~g} \mathrm{pot}^{-1}$ gives the effect of the number of leaves better than without $\mathrm{Si}$.

Increased plant height (Fig. 2) and number of leaf (Fig. 3) indirectly resulted in a better leaf area with Si (Fig. 4). This is in accordance with the opinion of Ahmad et al. (2012) that the maximum leaf area of the Chakwal-50 cultivar grain plant reaches $201.67 \mathrm{~cm}$ at a concentration of $<10 \% \mathrm{Si}$. This is in line with research of Ahmad et al. (2011) that an increase of Si up to $200 \mathrm{~m} \mathrm{~L}^{-1}$ under water tolerant conditions causes an increase in the area ef the sorghum leaf area.

Foliar Si could improve the leaf angle of plant crops so efficiently in the absorption of sunlight for photosynthesis.. As a result, it would increase the dry weight of plant (Fig. 5). Any increase of Si concentration of $1 \mathrm{ppm}$ will increase $0.022 \mathrm{~g}$ of dry weight of the plant. 


\section{Macrothink}

Journal of Agricultural Studies

ISSN 2166-0379

2018, Vol. 6, No. 3

Also, based on SPAD value (Table 3 and Fig. 11), there was relationship between the greenish of leaf and dry weight of plant wit $r=0.891$. It means there was a high correlation between greenish of leaf and dry weight of the plant. According to Locarno et al. (2010) that Si absorbed by plants will accumulate in the epidermis so that it is beneficial for better crop structure changes and better sunlight capture. Increasing the efficiency of sunlight absorption allows the activity of photosynthesis to run smoothly so as to affect the concentration of chlorophyll content in leaf tissue. The process of soybean photosynthesis with the foliar of $\mathrm{Si}$ is expected to produce more photosynthates, in the form of carbohydrates, starches, lipids, and proteins. The result of the photosynthate will be translocated in the plant so that the dry weight of plant also increases. Result of research show that the increase of Si can still increase dry weight of soybean crop. According to Rambo et al. (2011) that giving of 100 and $200 \mathrm{~kg} \mathrm{ha}^{-1}$ of Si can increase the dry weight of rice crop due to the accumulation of organic material in the photosynthesis process. The results also showed that the foliar of B with a concentration of $5 \mathrm{ppm}$ was able to produce dry weight of plant compared than without $\mathrm{B}$. This is in line with the study of Davis et al. (2003) that leaf B through concentration of 95.6 $\mathrm{mg} \mathrm{kg}^{-1}$ resulted in dry weight of tomato-tomatoes of 3.11 grams higher than without $\mathrm{B}$.

The greater the chlorophyll absorbance of leaves the greater the SPAD value, so it is predicted the level of green leaves will be greater. Jiang et al. (2017) states that SPAD-502 could be an effective tool used to estimate the leaf chlorophyll content in tomatoes quickly and nondestructively. The same is expressed by Rostini et al. (2003) that the chlorophyll content measured by SPAD 502 chlorophyll meter correlates with the weight of the soybean seed per plant. The longer the chlorophyll survives in the constant conditions supported by the amount of chlorophyll contained in the leaves, the higher the soybean yield.

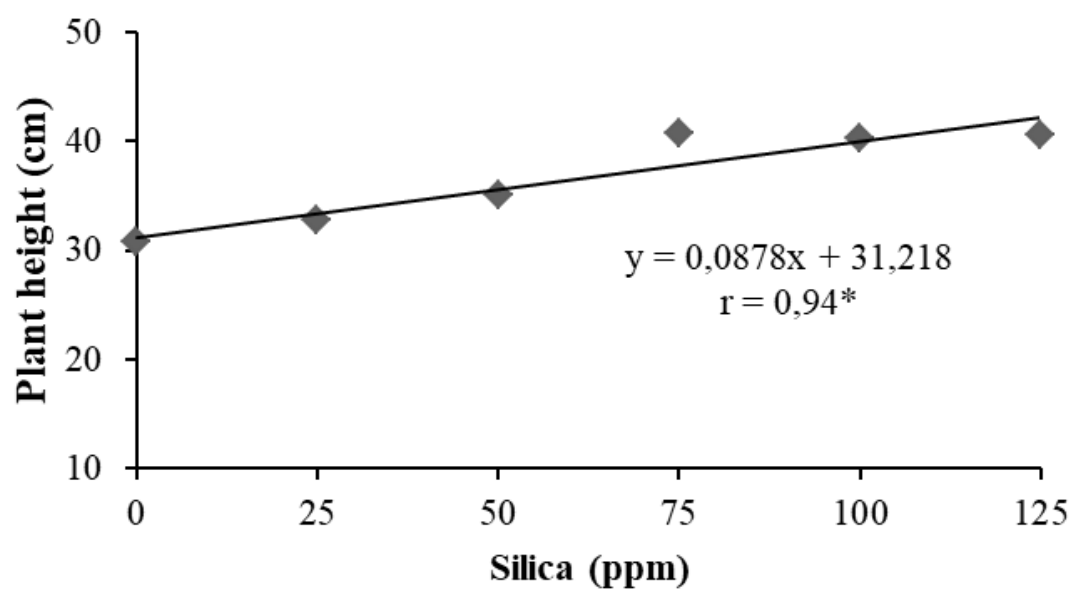

Figure 1. Response of the increasing concentration 


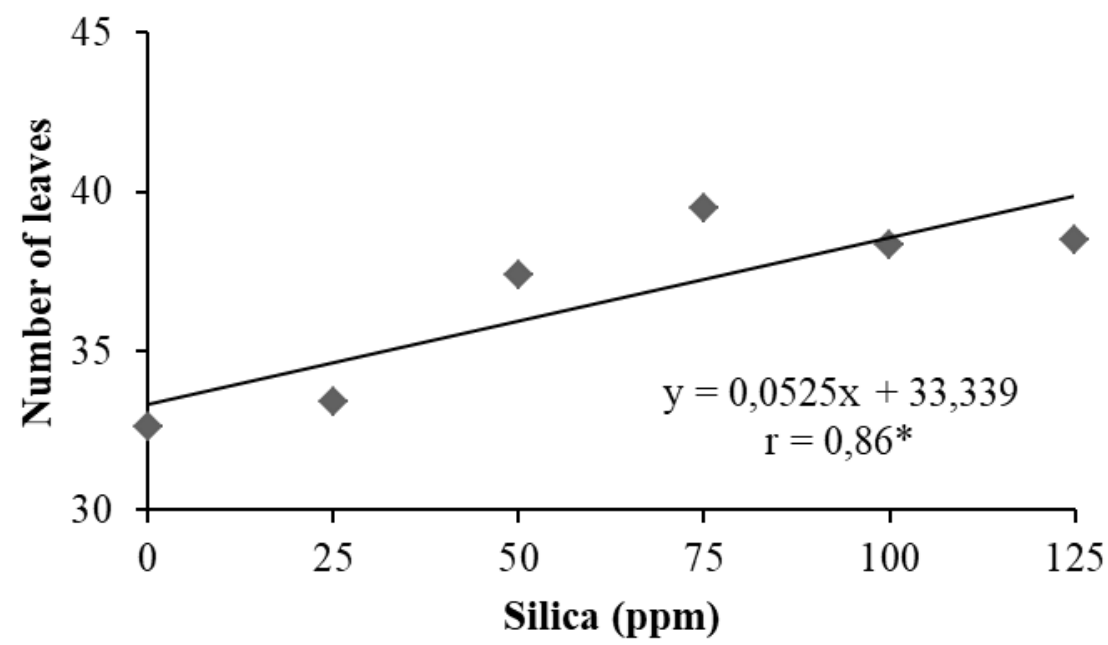

Figure 2. Response of the increasing concentration of $\mathrm{Si}$ on number of leaves.

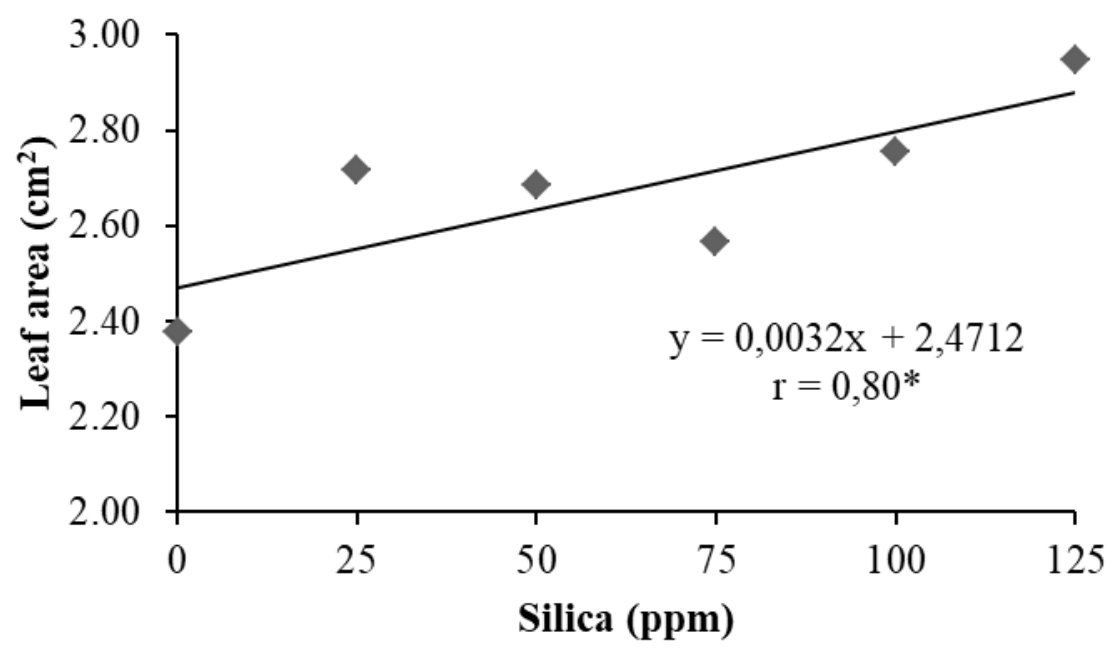

Figure 3. Response of the increasing concentration of Si on leaf area 


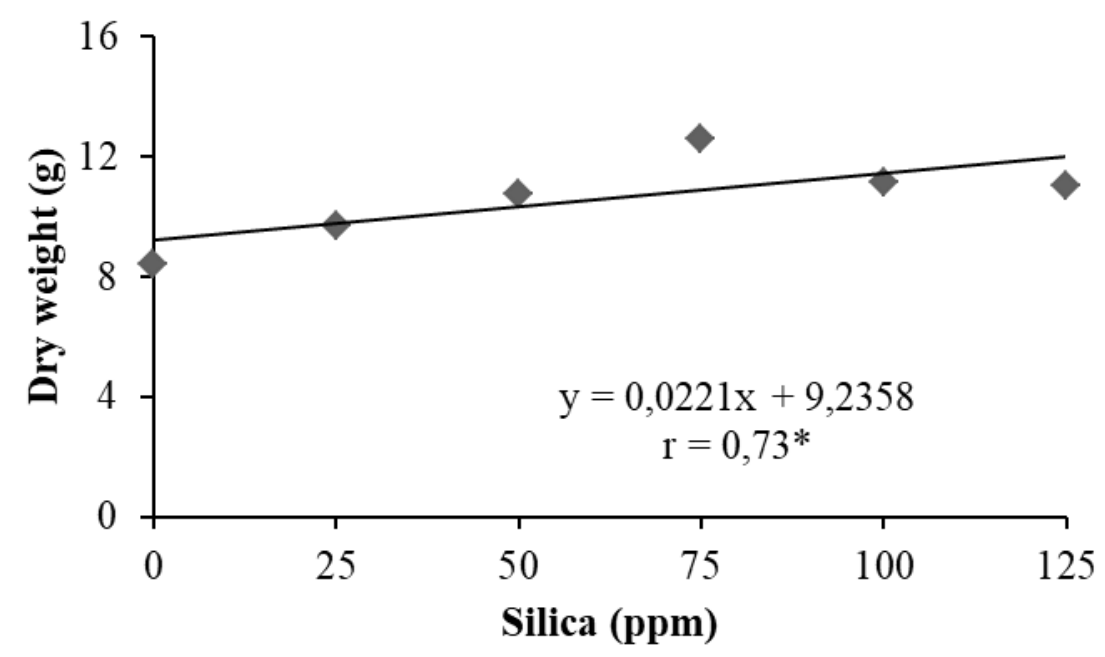

Figure 4. Response of the increasing concentration of on dry weight.

Good vegetative growth will produce high production. Makarim et al. (2007) explains that Si's benefits in gramminae plants, i.e. making upright leaves form efficiently capture solar radiation that will produce photosynthesis. The increase in Si concentration is expected to affect the number of productive branch (Fig. 6), number of pods (Fig. 7), and filled pods (Fig. 8), and grain weight (Fig. 9). The results showed that the number of productive branch, number of pods, and filled pods has a maximum point 71.68, 68.80, 66.86 ppm, respectively. It is suspected that the Si element entering the plant tissue accumulates in the endodermis. The accumulators in the endodermis cause $\mathrm{Si}$ to be an accumulator for the very important macro elements required by plants such as $\mathrm{N}, \mathrm{P}$, and $\mathrm{K}$. The macro element is blocked by the accumulation of $\mathrm{Si}$ in the endodermis so that it cannot be absorbed completely by the plant tissue.

According to Epstein (1994) Si has some of the following partial roles: (1) the availability of both ground and dissolved $\mathrm{Si}$ added to plant tissue is proportional to some macro element elements such as $\mathrm{N}, \mathrm{K}, \mathrm{Mg}, \mathrm{Ca}, \mathrm{S}$, and $\mathrm{P},(2)$ large $\mathrm{Si}$ is absorbed in the form of amorphous, $\mathrm{SiO}_{2} \cdot \mathrm{nH}_{2} \mathrm{O}$, or opal, the most important morphology and stockpiling of Si differ depending on the genotype of plants and environmental conditions, (3) $\mathrm{Si}$ sometimes reduces and eliminates the effects of excess P, heavy metals, salinity in the medium term. This is in accordance with the opinion of Sahebi et al. (2014) that Si's role in influencing growth, metabolism is not yet known, but the physiological role cannot be ignored because it can indirectly increase rice production.

According to Heckman (2009) one of the functions of B (Boron) is to assist the distribution of photosynthesis. This is in line with Makarim et al research. (2007) that adequate supply of photosynthate can store food reserves in the grain of rice. Increasing the supply of photosynthates will increase the amount of available food reserves so as to increase the number of pithy seeds. Increasing of pithy seeds will produce weight of 1000 seeds more 


\section{Macrothink}

Journal of Agricultural Studies

ISSN 2166-0379 2018, Vol. 6, No. 3

heavier. Similar results are expressed by Bellaloui et al. (2013), showed that foliar of B through the leaves was able to increase the weight of seed (weight of 100 seeds) by $16.1 \mathrm{~g}$ higher than without B by $13.2 \mathrm{~g}$ in soybean treated crops.

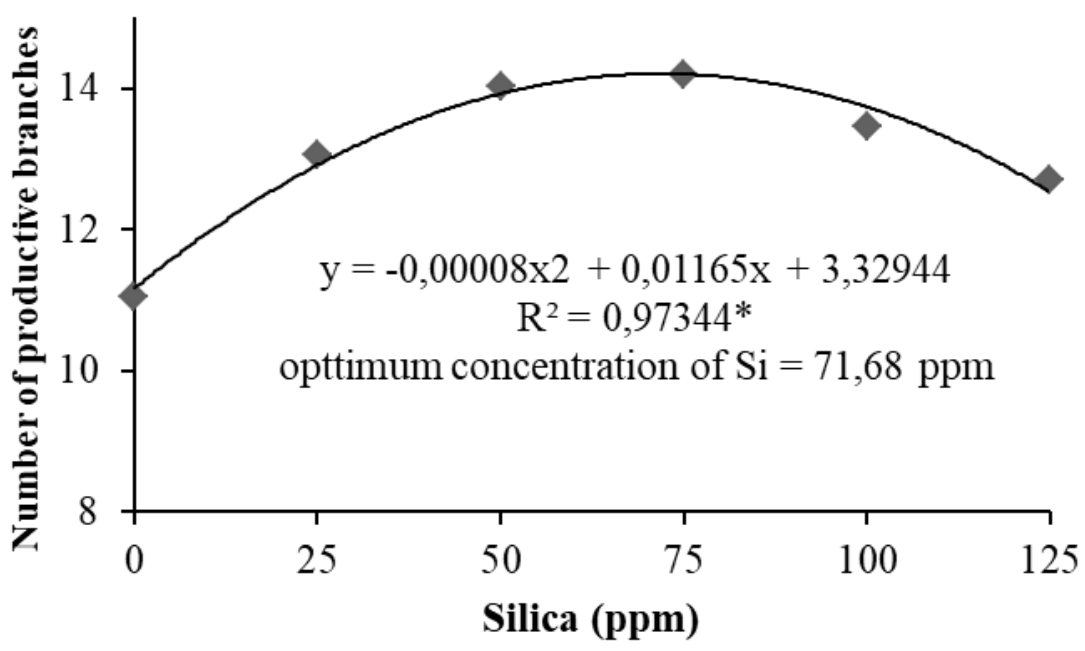

Figure 5. Response of the increasing concentration of Si on productive branches

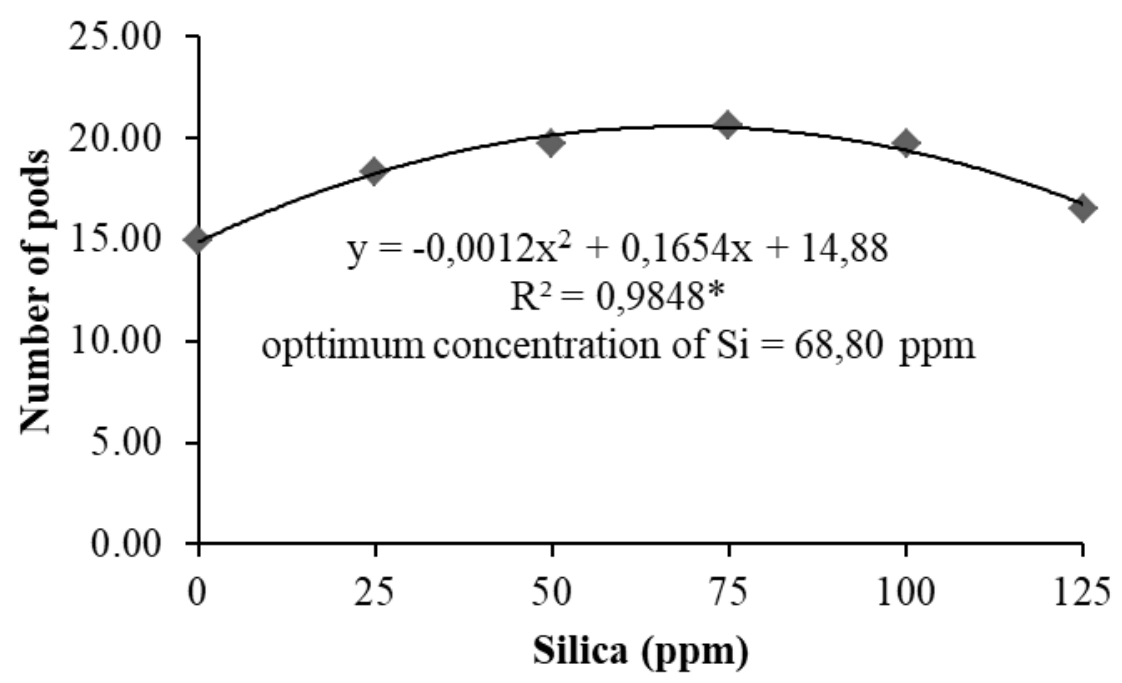

Figure 6. Response of the increasing concentration of Si on number of pods. 


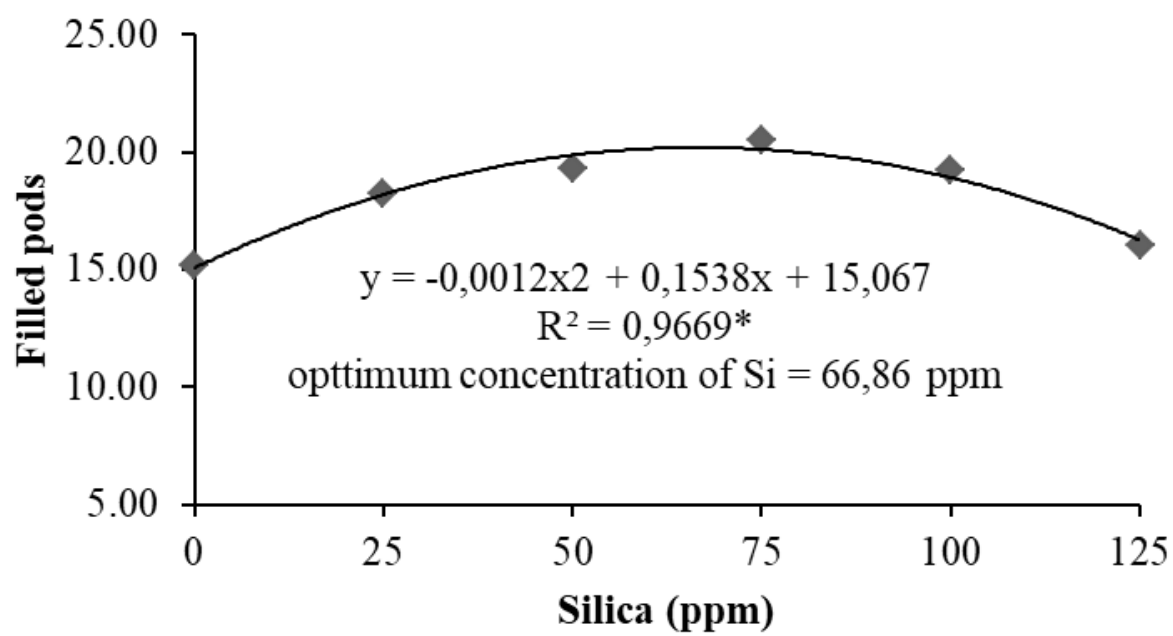

Figure 7. Response of the increasing concentration of Si on filled pods

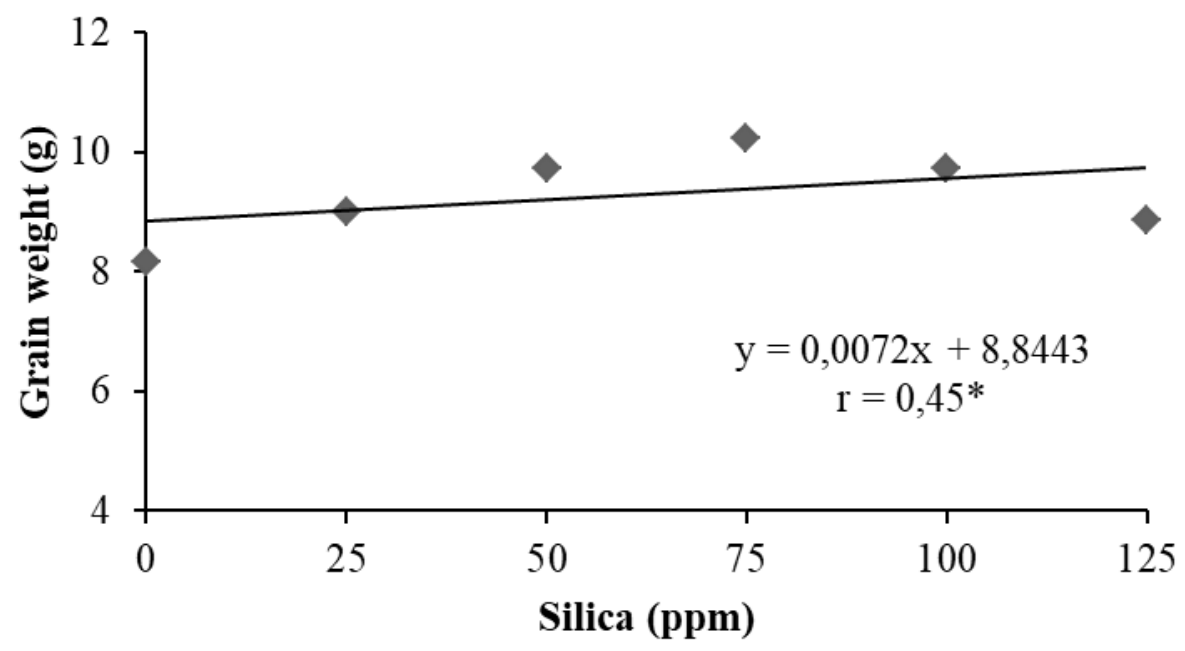

Figure 8. Response of the increasing concentration of Si on grain weight. 


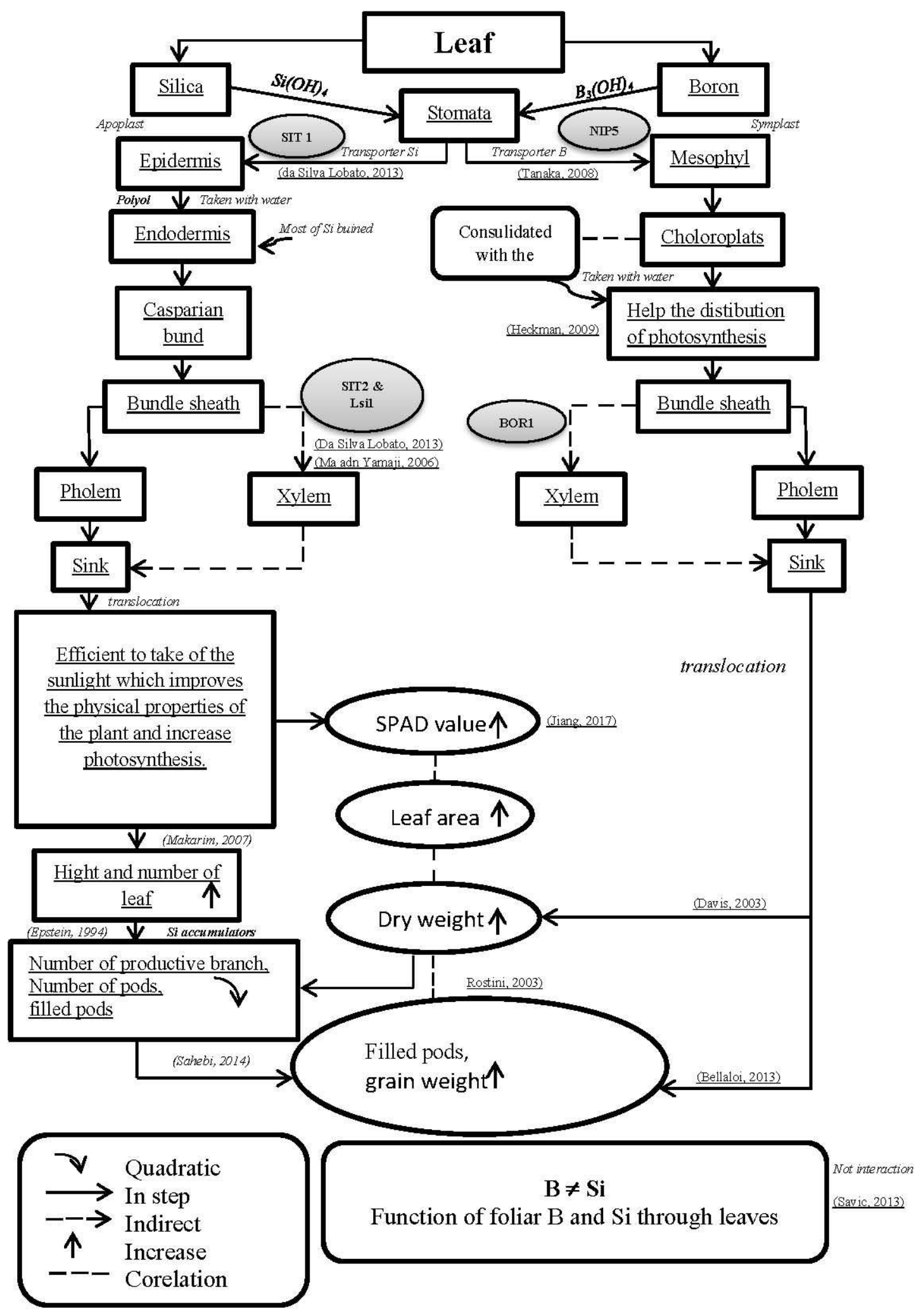

Figure 9. Proposed mechanism foliar B and Si through leaves in this research. 


\section{Conclusion}

Based on the research that has been done, then obtained the following conclusion: B foliar of $5 \mathrm{ppm}$ resulted in higher growth and soybean production compared to non-B through dry weighted variables (6.78\%) and grains weight (5.99\%). Foliar of $\mathrm{Si}$ up to $125 \mathrm{ppm}$ concentration can increase the growth and still increase the production of soybean crops through plant height, number of leaf, leaf area, dry weight; number of productive branch, number of pod, filled pods and grain weight of soybean, but no effect on percentage of empty void. The response of growth and production of soybeans to Si increase is independent of the foliar of B shown in all variables.

\section{References}

Ahmad, M., F. Ul-Hassen., U. Qadder., and M. A. Aslam. 2011. Silicon application and drought tolerance mechanism of sorgum. African Journal of Agricultural Research. 6 (3): 594-607. DOI: 10.5897/AJAR10.626

Central Beaureau of Statistic. 2015. Statistic Indonesian. In access http://www.bps.go.id/tnmn_pgn.php.

Bellaloui, N., Y. Hu, A. Mengistu, MA Kassem, and C. A. Abell. 2013. Effects of foliar boron application on seed composition, cell wall boron, and seed $\delta^{15} \mathrm{~N}$ and $\delta^{13} \mathrm{C}$ isotopes in water-stressed soybean plants. Journal Front Plant Science. (4) 270: 1-14.

DOI: $10.3389 /$ fpls.2013.00270

Brown, P.H., B.J. Shelp. 1997. Boron mobility in plants. Plant and Soil (193): 85-101

Costa, B.N.S., G.D.M.G. Dias., I.D.J.S. Costa., F.A.D. Assis., F.A.D. Silveira., M. Pasqual. 2016. Effect of silicon on the growth and genetic stability of passion fruit. Acta Scientiarum Agronomy. (38) 4: 503-511. DOI: 10.4025/actasciagron.v38i4.30939

Da Silva Lobato, A.K., E.M.S. Guedes., D.J. Marques., C.F.D.O. Neto. 2013. Silicon: A Benefic Element to Improve Tolerance in Plants Exposed to Water Dificiency. Intech. Chapter 5 .

Davis, J. dan L. Lengnick. 2003. Boron improves growth, yield, quality, and nutrient content of tomato. J. Amer. Soc. Hort. Sci. 128 (3): 441-446.

https://www.intagri.com/public_files/Sinergismo\%20de\%20boro\%20con\%20potasio\%20calc io $\% 20 \mathrm{y} \% 20$ fosforo.pdf

Epstein, E. 1994. The anomaly of silicon in plant biology. Procceding of the National Academy of Sicience. (91): 11-17. DOI: 10.1073/pnas.91.1.11

FAOSTAT. 2014. Soybean Production. In access http://www.fao.org/statistics/en/.

Heckman J. R. 2009. Boron: Needs of Soils and Crops in New Jersey.

http://www.rce.rutgers.edu.

Jiang, C., M. Johkan, M. Hohjo, S. Tsukagoshi, T. Maruo. 2017. A correlation analysis on chlorophyll content and SPAD value in tomato leaves. Hort Research. (71): 37-42. 


\section{NI Macrothink}

Journal of Agricultural Studies

ISSN 2166-0379

2018, Vol. 6, No. 3

Locarno. M., C.G. Fochi.; P.D.D.O. Paiva. 2010. Influence of silicate fertilization on chlorophylls of rose leaves. Ciencia Agrotecnologia. (35): 2: 287-290.

DOI: $10.1590 / \mathrm{S} 1413-70542011000200008$

Ma, J.F. and N. Yamaji. 2006. Silicon uptake and accumulation in higher plants. Trends in Plant Science. (11): 392-397. DOI: 10.1016/j.tplants.2006.06.007

Makarim, K., E. Suhartatik., And A. Kartohardjono. 2007. Silicon: Essential nutrients in Rice Production System. Rice Research Institute (2) 2: 195-204.

DOI: $10.1007 / \mathrm{s} 11104-015-2480-\mathrm{y}$

Miwa, K. and T. Fujiwara. 2010. Boron transport in plants: co-ordinated regulation of transporters. Annals of Botany. (105): 1103-1108. DOI: 10.1093/aob/mcq044

Prihartini, S., 2013. Effect of Boron and Silicone to the epidermis Root Strengthening Network Structure and Plant Growth Banana (Musa) 'Ambon Yellow'. Electronic Theses and Dissertation(ETD). in access

http://etd.repository.ugm.ac.id/index.php?mod=penelitiandetail\&sub=PenelitianDetail\&act=v iew\&typ=html\&buku_id=60269, On November 14, 2017. At 10:11 pm.

Rambo, M.K.D., L.C. Andre, B.B. Daiane, M.R. Tiele, A.R. Lucelia, H.K. Gaspar, F.M. Aryton. 2011. Silica from rice husk ash an additive for rice plant. Journal of Agronomy. (10) 3: 99-104. DOI: $10.3923 /$ ja.2011.99.104

Rostini, N., A. Baihkai, R. Setiamihardja., G. Suryatmana. 2003. Correlations of chlorophyll content and several leaf characters with yield in soybean. Zuriat. (14): 2.47-52. (In Indonesian)

Savic, J. dan M. Jeromale. A. 2013. Effect of silicon on sunflower growth and nutrient accumulation under low boron supply. Helia. 36 (58): 61-68.

DOI: $10.2298 /$ hel1358061s

Sommer M., D. Kaczorek., Y. Kuzyakou., dan J. Brever. 2006. Silicon pools and fluxes in soils and landscape. A reiview. J. Plant Soil Sci (169): 310-329.

DOI: $10.1002 /$ jpln.200521981

Sudaryono, Taufik A., and A. Wijanarko. 2007. Increased Opportunities Soybean production in Indonesia. In Soybean Production Engineering and Development, edited by Sumarno, Suyamto, Adi Widjono, Herman, and Husni Kasim. Agency for Agricultural Research and Development. Bogor. Pp 130-267.

Sukkaew, E., S. Amkha, T. Inboonchoy, dan T. Mala. 2016. Utilization of silicon fertilizer application on pepper seedling production. Modern Applied Science. (10) 11:264-272.

DOI: $10.5539 /$ mas.v10n11p264

Tanaka, M., I.S.Wallace., J. Takano., D.M. Roberts., dan T. Fujiwara. 2008. NIP6:1 Is a Boric acid channel for preferential transport of boron to growing shoot tissues in arabidopsis. The Plant Cel. (20): 2860-2875. DOI: 10.1105/tpc.108.058628 


\section{Macrothink}

Journal of Agricultural Studies

ISSN 2166-0379 2018, Vol. 6, No. 3

Timotiwu, P.B., W.A., Agustiansyah., E. Pramono, W.A. Vaolina. 2016. A Study of Boron and Silica Foliar Application on Growth and Yield of Rice in High Boron Content Media. Research in Agriculture . (1) 2: 58-65. DOI: http://dx.doi.org/10.22158/ra.v1n2p58

Yukamgo, E and NW Yuwono. 2007. Role of Nutrients Beneficial Silicones on Sugar Cane Plant. Journal of Soil and Environmental Sciences. (7). 2: 103-116. (In Indonesian)

\section{Copyright Disclaimer}

Copyright for this article is retained by the author(s), with first publication rights granted to the journal.

This is an open-access article distributed under the terms and conditions of the Creative Commons Attribution license (http://creativecommons.org/licenses/by/4.0/). 